\title{
Determining the optimal age of breeding gilts and its impact on lifetime performance Literature review
}

\author{
Malanda Joab \\ University of Debrecen, Faculty of Agricultural and Food Sciences and Environmental Management, \\ Department of Animal Science \\ mtolivet.livet@gmail.com
}

\begin{abstract}
SUMMARY
Lifetime sow performance is a critical indicator for producers managing a commercial sow herd. It is comprised of sow longevity, lifetime piglets born alive, lifetime number of pigs weaned and lifetime non-productive sow days. Increased lifetime performance and longevity in sows reduces costs of replacement gilts and improves herd performance and profitability (Sasaki et al., 2008, 2011). One of the most critical factors driving the performance of sow herds is gilt management. Decisions regarding gilts have profound effects on sows' lifetime performance. Age at first breeding of a gilt is a management decision that has been shown to affect performance and retention of the gilt in a herd. The main aim of this review is to establish factors affecting age of first breeding of gilts and its impact on lifetime performance.
\end{abstract}

Keywords: gilt management, age of breeding, lifetime performance, sow longevity

\section{INTRODUCTION}

Gilts constitute a significant proportion of the breeding females in most sow herds and an improvement in gilt management is likely to have a significant effect on overall herd performance. Fertility of sow herds is of great importance to overall sow herd management. One management decision to be made about gilts entering the herd is the optimal timing of first breeding of the gilt. Considerable variations have been noted regarding what is the preferred time to first breed the gilts basing on their attainment of puberty. Elliason et al. (1991) showed that Swedish Yorkshire gilts reach sexual maturity between 170 days to as late as 260 days of age. Similarly, Tummaruk et al. (2007) reported that sexual maturity occurred at 180 to 210 days of age, while the research finding of Evans and O'Doherty (2001) indicates a range of 200 to 220 days. In Finland, age at first estrus has been reported to occur at day 245 on Landrace gilts (Tummaruk et al., 2001). Even though, age at puberty can be genetically influenced (Evans and O'Doherty, 2001), different targets for breeding of gilts are recommended by various dam-lines companies. Furthermore, it has been shown that there is also relatively large variation in reproductive performance between sows, even if the sows are raised on the same farm (Iida and Koketsu, 2014). The main aim of this review is to establish factors affecting age of first breeding of gilts and its impact on lifetime performance.

\section{FACTORS AFFECTING AGE OF GILTS AT FIRST BREEDING}

The age of gilts at first-breeding is critical to optimize the lifetime reproductive performance of sows. Optimizing gilt performance requires proper herd introduction in terms of proper selection of replacement gilts based on many factors ranging from predicted reproductive ability to phenotypic production traits (Bidanel, 2011). The age of gilts at first-breeding is recorded in many North American swine farms, meaning it is an important variable in farm data analysis of piglets born alive and lifetime performance in commercial herds (Patterson et al., 2010). Herds contain a large proportion of gilts, breeding decisions on gilts could have a large influence on herd profits. The decision to start breeding gilts poses a considerable challenge for swine producers to consider other underlining factors.

\section{Gilt selection}

Comprehensive gilt selection is critical to lifetime success and productivity of a sow herd. Gilts that are purchased or retained as replacements should be genetically superior, reproductively sound, and structurally correct. The routine selection of gilts provides the opportunity to choose the best female for breeding which will impact the life performance in the herd, this selection varies based on production goals (Rzasa, 2007). It is nearly impossible to overcome poor gilt selection and development with later management actions in the breeding herd. Management programs dictate the future reproductive performance and longevity of the gilts in a herd. The age at puberty of gilts is defined as the time of the first estrus with ovulation as a reproductive indicator and a continuation of regular estrus cycles. However, onset of puberty is influenced by many factors, including genotype, technique and effectiveness of estrus detection, season, environment, boar exposure, nutrition, and health (Christenson, 1986).

The overall structure of an animal is the sum total of bone, muscle, fat and skin and how it is assembled to make an animal functional for a specific purpose. The first physical selection of breeding gilts should be done at weaning, selecting gilts by being focused on the health of the individuals and pre-weaning average daily gain (See, 2006). Second selection of breeding gilts should be by visual evaluation of structure with respect to underline, feet, legs, and external genitalia conducted at the age of 140 days (See, 2006). Breeding gilts must 
have at least seven functional nipples per side, be evenly spaced, and developed properly; not inverted. Hooves and legs indicate strength and durability for the gilt longevity. Breeding gilts should be able to move freely and get up and down easily. Furthermore, the breeding gilt should have a well-developed and wellshaped vulva, proportional in size, with the tip pointing downward.

\section{Gilt nutrition}

Swine producers target breeding gilts to achieve a high level of productivity throughout her lifetime. Nutrition and body composition can affect age at puberty and the ovulation rate, which in turn, can influence the productive lifetime performance of gilts (Kirkwood and Aherne, 1985). Modern maternal line genotypes are more sensitive to nutritional management because their appetite is lower and they have exceptional lean growth potential compared to genetics of 20 years ago (Bortolozzo et al., 2009). Gilts, which consume more feed, grow faster but tend to accumulate fat. Overweight gilts at breeding are a possible risk factor for reduced longevity and reduced herd reproductive efficiency (Calderón Díaz et al., 2015).

Breeding gilts are typically fed ad lib diet lower in energy than diets fed to slaughter pigs in order to avoid excessive body fat. The concerns of feed costs by pork producers during the non-productive period from selection to first breeding of gilts and into first pregnancy encourages some restriction of feeding that may be required to achieve the target fat and weight at age of first breeding. High fat addition in gilt diets could improve piglet weaning weight, but could also impair subsequent reproductive life performance by reducing LH (Luteinizing Hormone) secretion in early lactation (Kemp et al., 1995). Evidence from Foxcroft et al. (1996) support the concept of short-term "flushing" before first breeding to ensure potential ovulation rate of the gilt but should end immediately after breeding.

\section{Boar exposure}

Attainment of puberty in breeding gilts exposed to daily boar contact has been demonstrated to affect the age of first breeding (Brooks and Cole, 1970). Furthermore, majority of the factors that influence the efficacy of this boar effect include (i) the libido of the boar, (ii) the length of the daily boar exposure period, (iii) the number of gilts in the exposure group, and (iv) the size of the exposure pen. Boars must be mature and express the full complement of male mating characteristics. Exposure of peripubertal gilts to boars stimulates expression of estrus. However, van Wettere et al., (2006) suggested that first boar exposure should be delayed until 182 days of age because greater synchrony occurred within gilt groups. Furthermore, findings by Evans and O'Doherty (2001), indicates that differences in age at puberty of swine females may be attributed to genetic line differences and hence management practices concerning puberty induction should be adapted according to genotypes.
Breeding gilts that respond to boar exposure at an early age tend to remain in production for a longer lifetime than gilts that respond at a later age (Hoge and Bates, 2011). It is assumed that gilts that experience estrus within 30 days of boar stimulation will have more piglets in their first litter and reach greater lifetime productivity (Koketsu et al., 1999).

\section{Body weight}

Body weight and backfat thickness have an impact on gilt lifetime performance. The importance of a target weight of gilts at first breeding cannot be overemphasized since it has been reported by Kummer et al. (2006) to have an effect on lifetime performance. Bidanel et al. (1996) found that age at puberty has a high genetic correlation (0.84) with weight at puberty. Gilts intended for breeding should reach not only a certain minimum threshold of body weight at a specific age but also that of fatness, being expressed by backfat thickness before mating. Measurement of gilt backfat thickness (at 6-8 $\mathrm{cm}$ away from dorsal midline at the last rib curve) using ultrasonic probe works on the criterion of the reflection of sound wave, whereas optical probe works on the basis of light reflectance between muscles and fat depth, entailing the value of backfat thickness (Kempster et al., 1981). Though body weight and backfat thickness of the gilts are significantly related to age at puberty (Eliasson, 1991) but differs between breeds and genotypes (Henken et al., 1991). Tummaruk et al. (2000) reported, that Swedish Landrace gilts at $100 \mathrm{~kg}$ body weight, had a backfat thickness of $11.9 \mathrm{~mm}$ and were mated at day 237 as compared to Swedish Yorkshire gilts at 100kg body weight which had a backfat thickness of $12.3 \mathrm{~mm}$ and mated at day 249 in the same experiment. Later research findings from Tummaruk et al. (2009) between Landrace and Yorkshire gilts showed that replacement gilts should be bred at 240 days when 130 $\mathrm{kg}$ body weight with $17 \mathrm{~mm}$ backfat thickness. Though Kummer et al. (2006) had suggested that gilts should be first inseminated at a target weight between $135-150 \mathrm{~kg}$ which appears to be in tandem with Pig Improvement Company (PIC) 2015 that recommends breeding gilts at $136-145 \mathrm{~kg}$.

\section{Seasonality}

Many pork producers experience seasonal variation in reproductive performance of their sow herd. The effect of season on fertility is mediated by temperature and photoperiod (Britt et al., 1983). Heat stress is most detrimental to reproductive performance and it occurs when ambient temperatures are outside of the animals' thermoneutral zone. Pigs are very sensitive to ambient temperatures, especially in the absence of proper ventilation this can make pigs quickly become overheated. Most farms in North America experience seasonal infertility caused by estrus failure in breeding gilts and weaned sows and pregnancy failure (Knox et al., 2013). It has been shown that the farrowing rate is lower in spring and summer than in winter (Peltoniemi et al., 1999). Additionally, gilts born in the spring reach 
puberty later than those born in autumn, (Irgang et al., 1993).
Table 1 shows the summary of factors affecting age of gilts at first service according to literature.

Summary of factors affecting age of gilts at first service

\begin{tabular}{ll}
\hline & Reference \\
\hline $\begin{array}{l}\text { Gilt selection } \\
1^{\text {st }} \text { selection at weaning time }\end{array}$ & See (2006) \\
$2^{\text {nd }}$ selection at 140 days & See (2006) \\
\hline Boar exposure & Magnabosco D et al. (2014) \\
Early start at 140 days & Wettere et al. (2006) \\
Delayed start at 182 days & \\
\hline Body Weight (BW) and Back Fat (BF) & Bidanel et al. (1996) \\
0.84 correlation of age at puberty with weight at puberty & Tummaruk P et al. (2000) \\
Landrace 100kg BW attains 11.9mm BF and bred at day 237 & Tummaruk P et al.(2000) \\
Yorkshire 100kg BW attains 12.3mm BF and bred at day 249 & Kummer et al. (2006) \\
Camborough breed 135-150kg BW & Tummaruk et al. (2009) \\
Landrace and Yorkshire 130kg BW; 17mm BF; bred at 240 days & PIC (2015) \\
PIC hybrid 136-145kg BW; bred at 200-210 days & \\
\hline Nutrition & Foxcroft et al. (1996) \\
Short term flushing shortly before breeding and end after breeding &
\end{tabular}

\section{GILT PERFORMANCE}

It is especially important to ensure that there are sufficient breeding gilts available to serve in the correct condition, at the required time. Annual measurements of herd performance for females in high-performing herds based on the number of pigs weaned per mated females per year (PWMFY) have been reported to provide productivity and lifetime performance benchmarks for the swine industry (Koketsu, 2007). Gilt reproductive performance includes both prolificacy (pigs born alive) and fertility (weaning-tofirst-mating interval). Non-productive days of breeding gilts and sows increase when abortions occurs in commercial herds (Iida and Koketsu, 2015). Prolificacy is mainly affected by increasing ovulation rates and decreasing embryonic or fetal survival rates (Vinsky et al., 2006).

\section{Gilt Productive lifetime}

The length of productive life (LPL) (the number of days between gilt age at first mating and gilt/sow age at weaning of her last farrowing) and lifetime production traits (the sum of all individual measurements of each trait during the lifetime of a sow) are very important for the profitability of swine production systems because of their association with stayability, productivity and the cost of production. Increasing a gilt's LPL results in higher sow lifetime productivity and lower gilt replacement costs (Sasaki and Koketsu, 2008). A gilt remaining in the breeding herd for fewer parities is likely to produce fewer pigs in her lifetime, compared to a gilt that remains in the breeding herd for a longer period of time. In pig production, genetic replacement of sows is a major cost of operation and one of the most important management decisions for a producer to make as it is interrelated with numerous other factors that ultimately impact the system's cost-efficiency (Dhuyvetter, 2000).

From an economic point of view, sows should be kept in the herd as long as the expected profit for the next parity is higher than the lifetime average return from replacement gilt (Huirne et al., 1988; Dijkhuizen et al., 1989). However, Stalder et al., (2003) suggested that a sow needs to produce three litters to reach a positive net present value. For economic reasons, it is of great importance for the swine producer to have gilts with high annual productivity, achieved by gilts that reproduce well and remain in the herd for several parities. Usual reasons for removing sows from the herd are reproductive problems, age and disease (Stalder et al., 2004). Poor sow longevity in commercial pork production systems can lead to economic inefficiency and animal well-being concerns.

\section{Culling}

Traditionally, culling has been referred to as voluntary removal from the herd. The decision to replace sows depends mostly on average herd productivity. Different characteristics of sows, such as productivity, age at first farrowing, and stage within productive life, as well as living conditions and management practices within the farms, impact longevity (Le Cozler et al., 1998; Engblom et al., 2016). Culling is the ultimate consequence for sows with poor reproductive performance. Reproductive failure, encompassing a variety of problems including, but not limited to, failure to cycle and inability to conceive, is the single biggest reason for a sow's removal from the breeding herd (Pedersen, 1996) followed by issues related to problems with foot and leg structure. High average parity at removal or longevity has been 
associated with high breeding herd productivity (Dagorn and Aumaitre, 1979).

On commercial farms in the US, annual culling rates often exceed 50 percent and many sows are replaced before their third or fourth parity, corresponding to potentially the most productive period in the life of a sow (Hoge and Bates, 2011). With increasing cull rates, the percentage of breeding gilts increases, resulting in a larger proportion of gilt progeny of inferior performance and survivability (Mabry, 2016). The overall financial efficiency in pig herds decreases with increasing culling rates; as the average sow lifespan decreases, the number of piglets weaned per sow per year drops and the share of a sow in the cost per piglet increases (Lucia et al., 1999).

Longevity may also be influenced by the breed makeup of crossbred breeding females, Hall et al. (2002) noted that sows that were one-quarter Meishan had significantly higher mean days of productive lifetime (778 days) when compared to sows that were one-eighth Duroc or one-quarter Duroc (674 days and 639 days, respectively). This translated into a significantly higher mean parity at culling. However, offspring from Meishan litters may not be valued as highly in terminal markets.

\section{Death}

Mortalities in swine operations negatively impacts sow longevity and has economic implications. Mortality can make up a significant portion of the total sows removed from the breeding herd on an annual basis. Sow deaths, as a percentage of total breeding herd females, can commonly reach $10 \%$ or higher (Stein, et al., 1990). Disease is a contributing factor to sow mortality. Clinical parvovirus is recognized when a herd suffers an outbreak of SMEDI (Stillbirth, Mummification, Embryonic Death and Infertility). Porcine reproductive and respiratory syndrome (PPRS) is one of the most important diseases of intensive pig production worldwide. Annual total cost of PPRS in the US is reported to be USD663 million /year (Holtkamp et al., 2013). The economic impact of PRRS in breeding and farrowing units is caused mostly by a reduction in the number of weaned pigs and by an impairment of the farrowing rates. Herds infected with PRRS have increased abortion rates, forcing producers to face a decision whether to cull these females or to retain them and take a chance on their ability to rebreed. The most common causes for sow death include torsion and other abdominal organ injuries, heart failure, and cystitis (D’Allaire et al., 1999).

\section{CONCLUSION}

The aim of this review was to establish various factors that determine age at first breeding of gilts and its impact on lifetime performance. Age at first breeding of gilts is a management decision and therefore a factor to be considered for the initiation and retention of the gilts in a breeding herd. Initiating management practices that identify gilts with the greatest potential for lifetime performance is crucial to the productivity of swine production systems. Large range exists with respect to first day of breeding gilts from as low as 170 days of age to as high as 260 days of age. This large range appears to be too wide to be targeted on a well-managed sow herd because the number of estruses that gilts may be able to experience within this time range could be highly variable. There is no optimal age of first breeding gilts that results in greatest lifetime performance which can be recommended to swine producers. Therefore deciding when to first breed a gilt should be viewed as a challenge to swine producers. By analyzing lifetime data retrospectively, we would like to know the optimal age of breeding gilts that results in greatest lifetime performance. Implementing an effective gilt pool management strategy will allow producers to meet targets for body condition (weight, back fat) and physiological maturity (age, estrus at 1st breeding) which are key indicators in gilt management.

\section{REFERENCES}

Bidanel, J. P. (2011): Biology and genetics of reproduction. In: Rothschild MF, Ruvinsky A, eds. The Genetics of the Pig. Wallingford, UK: CAB International.222-232.

Bidanel, J. P.-Gruand, J.-Legault, C. (1996): Genetic variability of age and weight at puberty, ovulation rate and embryo survival in gilts and relations with production traits. Genet Sel Evol. 28:103115 .

Bortolozzo, F. P.-Bernardi, M. L.-Kummer, R.-Wentz, I. (2009): Growth, body state and breeding performance in gilts and primiparous sows. Soc Reprod Fertil. 66 (Suppl):281-291.

Britt, J. H.-Szarek, V. E.-Levis, D. G. (1983): Characterization of summer infertility of sows in large confinement units. Theriogenology. 20:133-40

Brooks, P. H.-Cole, D. J. A. (1970): The effect of the presence of a boar on the attainment of puberty in gilts. J. Reprod. Fertil. 23: $435-440$
Calderón Díaz, J. A.-Vallet, J. L.-Lents, C. A.-Nonneman, D. J.Miles, J. R.-Wright, E. C.-Rempel, L. A.-Cushman, R. A.Freking, B. A.-Rohrer, G. A.-Phillips, C.-DeDecker, A.Foxcroft, G.-Stalder, K. (2015): Age at puberty, ovulation rate, and uterine length of developing gilts fed two lysine and three metabolizable energy concentrations from 100 to $260 \mathrm{~d}$ of age. Journal of Animal Science.93:3521-3527

Christenson, R. K. (1986): Swine management to increase gilt reproductive efficiency. Journal of Animal Science.63:12801287

D’Allaire, S.-Drolet, R. (1999): Culling and mortality of breeding animals. In: Diseases of Swine, 8th Edition, Straw, B. E., D’Allaire, S., Mengeling, W. L. \& Taylor, D. J. (Eds) Iowa State University Press, Ames, Iowa, USA (1999) pp. 1003-1016

Dagorn, J.-Aumaitre, A. (1979): Sow culling: Reasons for and effect on productivity Livest.Prod.Sci.6:167-177 
Dhuyvetter, K. (2000): What Does Attrition Cost and What Is It Worth to Reduce? In, Retrieved from the University of Minnesota Digital Conservancy.

Dijkhuizen, A. A.-Krabbenborg, R. M. M.-Huirne, R. B. M. (1989) Sow replacement: a comparison of farmers' actual decisions and model recommendations. Livest. Prod. Sci. 23, 207-218.

Eliasson, L.-Rydhmer, S.-Einarsson, S.-Andersson, K. (1991) Relationship between puberty and production traits in the gilt. Age at puberty. Anim. Reprod. Sci. 25, 143-154

Engblom, L.-Calderon Diaz, J. A.-Nikkila, M.-Gray, K.-Harms, P.Fix, J.-Tsuruta, S.-Mabry, J.-Stalder, K. (2016): Genetic analysis of sow longevity and sow lifetime reproductive traits using censored data. J. Anim. Breed. Genet. 138-144

Evans, A. C. O.-O'Doherty, J. V. (2001): Endocrine changes and management factors affecting puberty in gilts. Livestock Production Science. 68:1-12

Foxcroft, G. R.-Cosgrove, J. R.-Aherne, F. X. (1996): Relationship between metabolism and reproduction. Proceedings of the $14^{\text {th }}$ IPVS Congress, Bologna, Italy 7-10 July 1996. pp 6-9

Hall, A. D.-Lo, S.-Rance, K. A. (2002): Comparative study of the lifetime productivity and performance characteristics of Meishan and Duroc cross-bred pigs. Acta Agriculturae Scandinavica Section A. 52: 183-188

Henken, A. M.-Brandsma, H. A.-Van der hel, W.-Verstegen, M. W. A. (1991): Difference in energy metabolism and protein retention of limit-fed growing pigs of several breeds. J. Anim. Sci. 69, 1443-1453.

Hoge, M. D.-Bates, R. O. (2011): Developmental factors that influence sow longevity. Journal of Animal Science.89:12381245.

Holtkamp, D. J.-Kliebenstein, J. B.-Neumann, E. J.-Zimmerman, J. J.-Rotto, H. F.-Yoder, T. K.-Wang, C.-Yeske, P. E.-Mowrer, C. L.-Haley, C. A. (2013): Assessment of the economic impact of porcine reproductive and respiratory syndrome virus on United States pork producers. J Swine Health Prod.21:72-84

Huirne, R. B. M.-Hendriks, T. H .B.-Dijkhuizen, A. A.-Giesen, G. W. J. (1988): The economic optimization of sow replacement decisions by stochastic dynamic programming. J. Agric. Econ. 39:426-438

Iida, R.-Koketsu. Y. (2014): Interactions between pre- or postservice climatic factors, parity, and weaning-to-first-mating interval for total number of pigs born of female pigs serviced during hot and humid or cold seasons. Journal of Animal Science. 92:4180 4188. doi:10.2527/jas.2014-7636

Iida, R.-Koketsu, Y. (2015): Climatic factors and risk factors associated with abortion occurrences in Japanese commercial pig herds. Anim Reprod Sci. 157: 78-86

Irgang, R.-Scheid, I. R.-Wentz, I. V. O.-Favero, J. A. (1993) Ovulation rate, embryo number and uterus length in purebred Duroc, Landrace and Large White gilts. Livest Prod Sci. 33:253266

Kemp, B.-Soede, N. M.-Helmond, F. A.-Bosch, M. W. (1995): Effects of energy source in the diet on reproductive hormones and insulin during lactation and subsequent estrus in multiparous sows. Journal of Animal Science.73:3022-3029

Kempster, A.-Chadwick, J.-Jones, D.-Cuthbertson, A. (1981): An evaluation of the hennessy and chong fat depth indicator, and the ulster probe, for use in pig carcass classification and grading. Journal of Anim Prod. 33(03): 319-324

Kirkwood, R. N.-Aherne, F. X. (1985): Energy intake, body composition and reproductive performance of the gilt. Journal of Animal Science .60: 1518-1529
Knox, R. V.-Rodriguez Zas, S. L.-Sloter, N. L.-McNamara, K. A.Gall, T. J.-Levis, D. G. et al. (2013): An analysis of survey data by size of the breeding herd for the reproductive management practices of North American sow farms. Journal of Animal Science.91:433-445

Koketsu, Y. (2007): Longevity and efficiency associated with age structures of female pigs and herd management in commercial breeding herds. Journal of Animal Science. 85: 1086-1091

Koketsu, Y.-Takahashi, H.-Akachi, K. (1996): Longevity, lifetime pig production and productivity, and age at first conception in a cohort of gilts observed over six years on commercial farms. J Vet Med Sci. 61:1001-1005

Kummer, R.-Bernardi, M. L.-Wentz, I-Bortolozzo, F. P. (2006): Reproductive performance of high growth rate gilts inseminated at an early age. Anim. Reprod. Sci., v.96, p.47-53.

Le Cozler, Y.-Dagorn, J.-Lindberg, J. E.-Aumaître, A.-Dourmad, J. Y. (1998): Effect of age at first farrowing and herd management on long-term productivity of sows. Livest. Prod. Sci. 53, 135142.

Lucia, T.-Dial, G. D.--Marsh, W. E. (1999): Estimation of lifetime productivity of female swine. J. Am. Vet. Med. Assoc. 214, 1056-1059

Mabry, J. (2016): How to Deal with Success in genetic improvement. $24^{\text {th }}$ International Pig Veterinary Society Congress 8th European Symposium of Porcine Health Management. pp. 64-72

Patterson, J. L.-Beltranena, E.-Foxcroft, G. R. (2010): The effect of gilt age at first estrus and breeding on third estrus on sow body weight changes and long-term reproductive performance. Journal of Animal Science .88:2500-13.

Pedersen, P. N. (1996): Longevity and culling rates in the Danish sow production and the consequences of a different strategy of culling. In: Proceedings of the Nordiska Jordbruksforskares Forening Seminar 265- Longevity of Sows. Danielsen, V. (Ed.) Denmark: Research Centre Foulum. pp. 28-33

Peltoniemi, O. A.-Love, R. J.-Heinonen, M.-Tuovinen, V.Saloniemi, H. (1999): Seasonal and management effects on fertility of the sow: a descriptive study. Anim Reprod Sci. 55:4761

PIC (2015): Sow and Gilt Management Manual, page 4. http://na.picgenus.com/sites/genuspic_com/Uploads/sowgilt_m anual.pdf

Rząsa, A. (2007): The effect of anatomical structure of sow teats or the assessment of serum anti-H. somnus on piglets' rearing results. Zeszyty Naukowe Uniwersytetu Przyrodniczego we Wrocławiu. Rozprawy. 549

Sasaki, Y.-Koketsu, Y. (2008): Sows having high lifetime efficiency and high longevity associated with herd productivity in commercial herds. Livestock Science. 118: 140-146.

Sasaki, Y.-Saito, H.-Shimomura, A.-Koketsu, Y. (2011): Consecutive reproductive performance after parity 2 and lifetime performance in sows that had reduced pigs born alive from parity 1 to 2 in Japanese commercial herds. Livestock Science. $139: 252-257$.

See, M. T. (2006): Selecting gilts for lifetime productivity. Paper presented at North Carolina Healthy Hogs Seminar.Clinton, NC

Stalder, K. J.-Knauer, M.-Baas, T. J.-Rothschild, M. F.-Mabry, J. W. (2004): Sow longevity.Pig News Inf., 25 pp. 53-74

Stalder, K. J.-Lacy, R. C.-Cross, T. L.-Conatser, G. E. (2003): Financial impact of average parity of culled females in a breedto-wean swine operation using replacement gilt net present value analysis. J. Swine Health Prod. 11: 69-74. 
Stein, T. E.-Dijkhuizen, A.-D’Allaire, S.-Morris, R. S. (1990): Sow culling and mortality in commercial swine breeding herds. Preventive Veterinary Medicine 9:85-94

Tummaruk, P.-Lundeheim, N.--Einarsson, S.-Dalin, A. M. (2000): Factors influencing age at first mating in purebred Swedish Landrace and Swedish Yorkshire gilts. J.Anim Reprod Sci. 63:241-253.

Tummaruk, P.-Lundeheim, N.-Einarsson, S.-Dalin, A. M. (2001) Effect of birth litter size, birth parity number, growth rate, backfat thickness and age at first mating of gilts on their reproductive performance as sows. Animal Reproduction Science. 66:225-237

Tummaruk, P.-Tantasuparuk, W.-Techakumphu, M.-Kunavongkrit, A. (2007): Age, body weight and backfat thickness at first observed estrus in crossbred Landrace $\times$ Yorkshire gilts, seasonal variations and their influence on subsequence reproductive performance. Animal Reproduction Science. 99:167-181.
Tummaruk, P.-Tantasuparuk, W.-Techakumphu, M.-Kunavongkrit A. (2009): The association between growth rate, body weight, backfat thickness and age at first observed estrus in crossbred Landrace $\times$ Yorkshire gilts. Anim Reprod Sci. 110:108-122.

Vinsky, M. D.-Novak, S.-Dixon, W. T.-Dyck, M. K.-Foxcroft, G. R. (2006): Nutritional restriction in lactating primiparous sows selectively affects female embryo survival and overall litter development. Reprod Fertil Dev. 18:347-55

Wettere, W. H.-Revell, D. K.-Mitchell, M.-Hughes, P. E. (2006): Increasing the age of gilts at first boar contact improves the timing and synchrony of the pubertal response but does not affect potential litter size. Animal Reproduction Science.95:97-106 